\title{
Effects of Quality of Energy Intake on Growth and Metabolic Response of Enterally Fed Low-Birth-Weight Infants
}

\author{
SUDHA KASHYAP, KIYOKO OHIRA-KIST, KIRSTEN ABILDSKOV, HELEN M. TOWERS, \\ RAKESH SAHNI, RAJASEKHAR RAMAKRISHNAN, AND KARL SCHULZE
}

Division of Neonatal-Perinatal Medicine, Department of Pediatrics, Babies and Children's Hospital of New York, College of Physicians and Surgeons, Columbia University, New York, New York 10032, U.S.A.

\begin{abstract}
ABST
Carbohydrate and fat may vary in their ability to support
protein accretion and growth. If so, variations in the source of
nonprotein energy might be used to therapeutic advantage in
enterally fed low-birth-weight infants. To test the hypothesis that
high-carbohydrate diets are more effective than isocaloric high-
fat diets in promoting growth and protein accretion, low-birth-
weight infants weighing $750-1600 \mathrm{~g}$ at birth were randomized in
a double blind study to receive one of five formulas differing only
in the quantity and quality of nonprotein energy. Groups 1,2 , and
control received $130 \mathrm{kcal} \cdot \mathrm{kg}^{-1} \cdot \mathrm{d}^{-1}$ with 35,65 , and $50 \%$ of the
nonprotein energy as carbohydrate. Groups 3 and 4 received
energy intake of $155 \mathrm{kcal} \cdot \mathrm{kg}^{-1} \cdot \mathrm{d}^{-1}$ with 35 and $65 \%$ of the
nonprotein energy as carbohydrate. Protein intake of all groups
was $4 \mathrm{~g} \cdot \mathrm{kg}^{-1} \cdot \mathrm{d}^{-1}$. Growth and metabolic responses were followed
weekly, and macronutrient balances including 6 -h indirect calo-
\end{abstract}
The American Academy of Pediatrics has suggested that a logical goal for nutritional support of the preterm LBW infant is to achieve postnatal growth approximating that of a normal fetus of the same postconceptional age $(1,2)$. Attempts to achieve this goal by feeding enriched diets have been successful in supporting the intrauterine rate of weight gain (3-7), but invariably these diets lead to a disproportionate increase in body fat. The reasons for this postnatal failure to maintain the high fetal rates of protein accretion relative to fat deposition are unknown. One difference between fetal and neonatal life is the relatively greater dependence of the fetus on carbohydrate versus fat as an energy source. If the fetus is relatively more dependent on carbohydrate than fat, then it is possible that the same is true of the fetus ex utero, i.e. the preterm LBW infant. This reintroduces a question of long-standing concern in develop-

Received July 28, 2000; accepted April 10, 2001.

Correspondence: Sudha Kashyap, M.D., Department of Pediatrics, College of Physicians and Surgeons, Columbia University, 630 West 168th Street, New York, NY 10032, U.S.A.; e-mail: sk48@columbia.edu

Supported by NIH Grants HD 27564, RR00645, and HD 13063. rimetry were performed biweekly. Greater rates of weight gain and nitrogen retention were observed at high-carbohydrate intake compared with high-fat intake at both gross energy intakes. Greater rates of energy storage and an increase in skinfold thickness were observed in group 4 (high-energy highcarbohydrate diet) despite higher rates of energy expenditure. These data support the hypothesis that at isocaloric intakes, carbohydrate is more effective than fat in enhancing growth and protein accretion in enterally fed low-birth-weight infants. However, a diet with high-energy and high-carbohydrate content also results in increased fat deposition. (Pediatr Res 50: 390-397, 2001)
LBW, low birth weight

mental nutrition, namely, do carbohydrate and fat differ in some fundamental way in their ability to support protein synthesis? Indeed, there is experimental evidence that supports the hypothesis that calorie for calorie, utilization of carbohydrate as an energy source is more effective than fat in supporting protein accretion (8-11); other research, however, asserts that this effect is transient (12). In enterally fed LBW infants, this hypothesis remains untested.

LBW infants are ideal subjects for studying this basic question. These infants are fundamentally healthy, their intakes can be controlled very precisely (within 1 to $2 \%$ ), their growth can be characterized over a period of time during which weight roughly doubles, their individual differences in physical activity, thermal environment, etc. can be quantified and/or controlled, and their responses to dietary intervention are directly and immediately relevant to clinical care of other LBW infants as well as other populations of patients.

The purpose of the present study was to test the hypothesis that high-carbohydrate diets are more effective than isocaloric high-fat diets in promoting growth and protein accretion in enterally fed LBW infants. 


\section{METHODS}

LBW infants weighing between 750 and $1600 \mathrm{~g}$ at birth who were without gastrointestinal, renal, or severe pulmonary disease were assigned in a random double-blind fashion to be fed one of five experimental formulas. All the formulas were designed to provide protein intakes of $4 \mathrm{~g} \cdot \mathrm{kg}^{-1} \cdot \mathrm{d}^{-1}$ when fed at $180 \mathrm{~mL} \cdot \mathrm{kg}^{-1} \cdot \mathrm{d}^{-1}$. Formulas 1 and 2 were designed to provide $120 \mathrm{kcal} \cdot \mathrm{kg}^{-1} \cdot \mathrm{d}^{-1}$ when fed at this daily volume. The carbohydrate and fat contents of the formulas were varied to provide $35 \%$ of the nonprotein energy as carbohydrate in formula 1 and $65 \%$ of the nonprotein energy in formula 2. Formulas 3 and 4 were designed to provide higher energy intakes of $150 \mathrm{kcal}$. $\mathrm{kg}^{-1} \cdot \mathrm{d}^{-1}$ when fed at $180 \mathrm{~mL} \cdot \mathrm{kg}^{-1} \cdot \mathrm{d}^{-1}$ with nonprotein energy as 35 and $65 \%$ from carbohydrate. An additional control formula was designed to provide $120 \mathrm{kcal} \cdot \mathrm{kg}^{-1} \cdot \mathrm{d}^{-1}$ with $50 \%$ of the nonprotein energy as carbohydrate when fed at the same volume. Stratified randomization was done within three birthweight ranges, i.e. $750-1000,1001-1300$, and $1301-1600 \mathrm{~g}$. All the formulas were made specifically for this study by Ross Laboratories. Formula bottles were number coded, and the code was not known to the investigators. The protein content of the formulas was modified bovine milk protein with a $60: 40$ ratio of whey proteins to caseins. The carbohydrate content was composed of equal amounts of lactose and corn syrup solids, and the fat was provided by a mixture of coconut, soy, and safflower oils. The electrolyte, mineral, and vitamin contents of the formulas were similar. The actual macronutrient contents of the formulas are given in Table 1.

The assigned formula was started as soon as enteral feedings were tolerated by the infant, and the volume of formula was increased as tolerated until the desired intake of $180 \mathrm{~mL}$. $\mathrm{kg}^{-1} \cdot \mathrm{d}^{-1}$ was achieved. This volume was adjusted daily and maintained throughout the study, that is, until weight reached $2200 \mathrm{~g}$ or the infant was discharged. During this period, the infants were nursed in servocontrolled single-walled incubators under thermoneutral conditions. Formulas were delivered either by orogastric tube or by nipple. Vitamin E (25 IU) and a mixture of vitamins A (1500 IU), C (35 mg), and D (400 IU) were administered daily after feedings were established. Shortly after enrollment, as soon as medically permitted, the infants were transferred to the General Clinical Research Center where they remained until discharge. Growth, nutrient balances, and biochemical variables were monitored as described below from the time the desired intake was achieved until weight reached $2200 \mathrm{~g}$ or until the infant was discharged. Feeding tolerance was assessed by monitoring gastric residuals, abdominal distension, and the frequency and consistency of stools.

The present study was approved by the Institutional Review Board of the College of Physicians and Surgeons of Columbia University, Columbia-Presbyterian Medical Center. Written informed parental consent was obtained before an infant was enrolled.

Growth. Body weight was determined each morning before feeding by using a scale with a resolution of $1 \mathrm{~g}$. The daily weights of each infant were regressed against the infant's age in days, and the rate of weight gain over the study period, expressed as $\mathrm{g} \cdot \mathrm{kg}^{-1} \cdot \mathrm{d}^{-1}$, was computed (using an exponential model,

$$
\mathrm{W}=\mathrm{W}_{\mathrm{o}} \mathrm{e}[\Delta \mathrm{t} / 1000]
$$

where $\mathrm{W}$ is the weight at age $t, \mathrm{~W}_{\mathrm{o}}$ is the birth weight, and $\Delta$ is the weight gain in $\mathrm{g}^{\mathrm{kg}} \mathrm{kg}^{-1} \cdot \mathrm{d}^{-1}$ ) for each infant.

Crown-heel length, head circumference, and the thickness of triceps and subscapular skinfolds were measured weekly, always by the same two investigators, using standard procedures (13). Each measurement was regressed against postnatal age, and the rates of change over the entire study period expressed as $\mathrm{cm}$ or $\mathrm{mm} / \mathrm{wk}$ were computed. The study period ranged from 13 to $54 \mathrm{~d}$ (mean $\pm \mathrm{SD}, 26.1 \pm 10.2 \mathrm{~d}$ ) for the control group, from 13 to $47 \mathrm{~d}$ $(25.9 \pm 10.3 \mathrm{~d})$ for group 1 , from 14 to $48 \mathrm{~d}(25.3 \pm 10.3 \mathrm{~d})$ for group 2 , from 13 to $37 \mathrm{~d}(25.4 \pm 7.2 \mathrm{~d})$ for group 3 , and from 14 to $37 \mathrm{~d}(21.9 \pm 7.7 \mathrm{~d})$ for group 4 .

Nutrient balances. Seventy-two-hour collections of stool and urine were performed using standard procedures described previously (4). Balances were measured within the first week

Table 1. Composition of the two lots of experimental formulas

\begin{tabular}{|c|c|c|c|c|c|}
\hline $\begin{array}{c}\text { Components } \\
\text { (per liter) }\end{array}$ & $\begin{array}{c}\text { Control } \\
50 \% \mathrm{CHO}\end{array}$ & $\begin{array}{l}\text { Formula } 1 \\
35 \% \mathrm{CHO}\end{array}$ & $\begin{array}{l}\text { Formula } 2 \\
65 \% \text { CHO }\end{array}$ & $\begin{array}{l}\text { Formula } 3 \\
35 \% \text { CHO }\end{array}$ & $\begin{array}{l}\text { Formula } 4 \\
65 \% \text { CHO }\end{array}$ \\
\hline \multicolumn{6}{|l|}{ Protein (g) } \\
\hline Lot 1 & $21.8 \pm 0.3$ & $23.2 \pm 0.3$ & $22.0 \pm 0.5$ & $23.9 \pm 0.1$ & $22.5 \pm 0.1$ \\
\hline Lot 2 & $22.4 \pm 0.7$ & $23.2 \pm 0.7$ & $23.3 \pm 0.7$ & $22.8 \pm 0.2$ & $22.5 \pm 0.5$ \\
\hline \multicolumn{6}{|l|}{ Energy (kcal) } \\
\hline Lot 1 & $737 \pm 9.2$ & $745 \pm 12.2$ & $686 \pm 12.8$ & $865 \pm 16.4$ & $862 \pm 16.7$ \\
\hline Lot 2 & $718 \pm 14.6$ & $731 \pm 5.1$ & $732 \pm 9.7$ & $866 \pm 5.5$ & $851 \pm 17.0$ \\
\hline \multicolumn{6}{|l|}{ Fat (g) } \\
\hline Lot 1 & $36.1 \pm 0.3$ & $45.1 \pm 0.3$ & $24.0 \pm 0.2$ & $53.3 \pm 0.3$ & $30.0 \pm 0.4$ \\
\hline Lot 2 & $33.0 \pm 0.2$ & $43.0 \pm 0.1$ & $23.9 \pm 0.2$ & $52.7 \pm 0.2$ & $29.6 \pm 0.5$ \\
\hline \multicolumn{6}{|l|}{ Calcium (mg) } \\
\hline Lot 1 & $1357 \pm 24$ & $1460 \pm 33$ & $1462 \pm 35$ & $1446 \pm 48$ & $1391 \pm 35$ \\
\hline Lot 2 & $1443 \pm 38$ & $1290 \pm 33$ & $1452 \pm 41$ & $1412 \pm 37$ & $1456 \pm 35$ \\
\hline \multicolumn{6}{|c|}{ Phosphorus (mg) } \\
\hline Lot 1 & $687 \pm 22$ & $691 \pm 21$ & $722 \pm 11$ & $683 \pm 12$ & $689 \pm 11$ \\
\hline Lot 2 & $608 \pm 16$ & $615 \pm 9$ & $686 \pm 16$ & $649 \pm 11$ & $639 \pm 12$ \\
\hline
\end{tabular}

Mean \pm SD of six to nine analyses of each formula performed over the study period.

$\mathrm{CHO}=$ carbohydrate. 
after the infants had received the desired intake of $180 \mathrm{~mL}$. $\mathrm{kg}^{-1} \cdot \mathrm{d}^{-1}$ and every other week thereafter until weight reached $2200 \mathrm{~g}$ or, occasionally, until the child was discharged at a slightly lower weight. Two collections were obtained from 48 infants, three collections from 14 infants, and four collections from one infant.

Nitrogen, fat, and mineral balances were computed as the difference between intake and the sum of urinary and fecal losses. Total nitrogen content of the formulas, urine, and stool was measured by the Dumas method by using a Coleman model 129 automatic nitrogen analyzer (Perkin-Elmer Corp., Norwalk, CT, U.S.A.). Concentrations of calcium were determined by atomic absorption spectrometry and those of phosphorus by the method of Baginski et al. (14).

Energy balance (i.e. energy stored) was also determined during each 72-h urine and stool collection period and was computed as the difference between gross energy intake and the sum of excretory energy losses and energy expenditure. The energy contents of the intake and stool were determined by bomb calorimetry (15); the energy content of urine was calculated as $5.4 \mathrm{kcal} / \mathrm{g}$ of urine urea excretion [the heat of combustion of urea (16)]. Energy expenditure was computed from 6-h measurements of oxygen consumption and carbon dioxide production and from urinary nitrogen excretion during the 72-h collection period by using the constants of Lusk (17). The open-circuit indirect calorimetry system used to measure oxygen consumption and carbon dioxide production has been described previously (3).

Composition of weight gain. The protein content of weight gain (protein stored) was calculated as $6.25 \times$ nitrogen balance in $\mathrm{g} \cdot \mathrm{kg}^{-1} \cdot \mathrm{d}^{-1}$. The fat content of the weight gain (fat stored) was calculated as

Fat stored $=[$ Energy stored $-5.65($ protein stored $)] 9.25$

where energy is expressed as $\mathrm{kcal} \cdot \mathrm{kg}^{-1} \cdot \mathrm{d}^{-1}$ and protein and fat stored as $\mathrm{g}^{\mathrm{kg}} \mathrm{g}^{-1} \cdot \mathrm{d}^{-1}$, and the constants 5.65 and 9.25 are energy equivalents of protein and fat $(\mathrm{kcal} / \mathrm{g})$ of dairy products (18). The change in the small amount of energy likely to be stored as carbohydrate [i.e. from $0.45 \%$ of body weight in the 31 -wk fetus to $0.9 \%$ of body weight in the term infant $(19,20)]$ was not estimated.

Biochemical variables. Plasma albumin, transthyretin, and amino acid concentrations were determined every other week. Plasma blood urea nitrogen (BUN) concentrations and acid base status were determined weekly. Plasma triglyceride concentrations were determined in the last week of the protocol. Plasma albumin and BUN concentrations and acid base status were determined by the Clinical Chemistry Laboratory of New York Presbyterian Hospital. Plasma transthyretin was determined by radial immunodiffusion by use of an M-Partigen kit (Behring Diagnostics, La Jolla, CA, U.S.A.), and plasma amino acids were determined by column chromatography by use of a Beckman 6300 amino acid analyzer (Beckman Instruments, Inc., Palo Alto, CA, U.S.A.). Plasma triglyceride concentrations were determined using an enzymatic triglyceride test kit (Boehringer Diagnostics). Urinary C-peptide was determined during the study period by RIA (INCSTAR).
Data analysis. Clinical characteristics assessable on a continuous scale were summarized as mean $\pm \mathrm{SD}$; dichotomous characteristics (present/absent) were summarized by enumerating the number of subjects with each characteristic.

The mean slope of the linear regression of each outcome variable against postnatal age was calculated for each group, using the slope of each subject, and tested to determine whether it was significantly different from zero. If so, the slope of the variable and the mean value were used as outcome measurements for further analyses. For variables that did not change significantly with time, the mean of all values obtained during the period of study for each subject was used for further analysis.

Data were analyzed using ANOVA with specific contrasts incorporated into the model using indicator variable (21). Comparisons were made of high versus low-carbohydrate intake at both gross energy intakes.

\section{RESULTS}

Of the 68 infants randomly and prospectively assigned to the five formulas, 63 completed the protocol. Two infants were withdrawn from the protocol because they developed a patent ductus arteriosus requiring fluid restriction (one each from group 1 and 4), two infants developed necrotizing enterocolitis (one from group 2 and one from group 3), and one infant (from group 1) was inadvertently taken off the study formula before completing the protocol. As summarized in Table 2, the clinical characteristics of the 63 infants who completed the study differed minimally among the groups.

All the formulas were well tolerated by the infants. Although the consistency of stool of infants on the high-fat formula tended to be firmer, there were no differences in the frequency of stools between the groups $(2.8 \pm 1.0$ versus $2.3 \pm 0.8$ and $2.8 \pm 1.1$ versus $2.4 \pm 0.9$ stools $/ \mathrm{d}$ in groups 1 versus 2 and 3 versus 4 , respectively, and $2.0 \pm 0.6$ stools/d in the control group).

Nutrient intakes. The mean volume of formula intake of all infants was very close to that intended. Thus, the actual intakes of these groups differed only minimally from expected intakes based on the nutrient contents of the formulas (Table 1). The mean intake of major nutrients in each of the five groups is summarized in Table 3. The measured energy content of the formulas was slightly higher than planned in the study design; the mean energy intakes of groups 1,2, and control were 130 $\mathrm{kcal} \cdot \mathrm{kg}^{-1} \cdot \mathrm{d}^{-1}$ and those of groups 3 and 4 were 155 $\mathrm{kcal} \cdot \mathrm{kg}^{-1} \cdot \mathrm{d}^{-1}$.

Growth. The rates of weight gain $(\Delta \mathrm{wt})$ of infants randomized to high-carbohydrate diets (groups 2 and 4 ) were significantly greater than those of infants receiving the high-fat diets (groups 1 and 3) at both energy intakes of $130 \mathrm{kcal}$ and 155 $\mathrm{kcal} \cdot \mathrm{kg}^{-1} \cdot \mathrm{d}^{-1}$ (Table 4). The rates of increase in crown-heel length and skinfold thickness (triceps + subscapular) of infants assigned to the high-energy and high-carbohydrate diet (group 4) were significantly greater than those of infants fed the high-fat diet at the same energy intake. The mean rates of increase in head circumference were consistently greater in the 
Table 2. Characteristics of the study population

\begin{tabular}{|c|c|c|c|c|c|}
\hline Variable & $\begin{array}{c}\text { Control } \\
130 \mathrm{kcal} \\
50 \% \mathrm{CHO} \\
(n=14)\end{array}$ & $\begin{array}{c}\text { Group } 1 \\
130 \mathrm{kcal} \\
35 \% \mathrm{CHO} \\
(n=11)\end{array}$ & $\begin{array}{c}\text { Group } 2 \\
130 \mathrm{kcal} \\
65 \% \mathrm{CHO} \\
(n=12)\end{array}$ & $\begin{array}{c}\text { Group } 3 \\
155 \mathrm{kcal} \\
35 \% \mathrm{CHO} \\
(n=14)\end{array}$ & $\begin{array}{c}\text { Group } 4 \\
155 \mathrm{kcal} \\
65 \% \mathrm{CHO} \\
(n=12)\end{array}$ \\
\hline $750-1000 \mathrm{~g}$ & 2 & 2 & 3 & 2 & 2 \\
\hline $1001-1300 \mathrm{~g}$ & 5 & 4 & 4 & 5 & 4 \\
\hline $1301-1600 \mathrm{~g}$ & 7 & 5 & 5 & 7 & 6 \\
\hline $30-32$ wk & 6 & 7 & 2 & 5 & 4 \\
\hline$>32 \mathrm{wk}$ & 2 & 2 & 3 & 3 & 5 \\
\hline \multicolumn{6}{|l|}{ Weight for GA (percentile) } \\
\hline$<10$ th & 1 & 1 & 0 & 1 & 4 \\
\hline 10th-25th & 6 & 4 & 4 & 6 & 4 \\
\hline 25 th -50 th & 4 & 3 & 7 & 6 & 2 \\
\hline
\end{tabular}

Mean \pm SD.

$\mathrm{GA}=$ gestational age. $\mathrm{CHO}=$ carbohydrate.

high-carbohydrate versus the high-fat diet at both energy intakes; however, these differences were not significant.

Nutrient balances. The mean within-subject variability for nitrogen balance, metabolizable energy intake, and energy expenditure was $7.9,3.1$, and $5.9 \%$, respectively. The rate of nitrogen retention of infants on high-carbohydrate diets was significantly greater than that of the infants receiving the high-fat diets at similar energy intakes. However, as noted in Table 3, the metabolizable energy intakes of groups 2 and 4 (the high-carbohydrate intake groups) are slightly higher than those of the comparable high-fat intake groups, raising the possibility that the enhanced nitrogen retention was merely an effect of greater metabolizable energy intake. Because nitrogen intake of all diet groups was roughly the same, it is possible to examine the relationship between the mean nitrogen excretion (urine + stool) and the quantity and quality of gross energy intake and metabolizable energy. Nitrogen excretion is significantly related to carbohydrate energy intake $(y=267-$ $1.16 \mathrm{x} ; p=0.013)$ and to metabolizable energy as carbohydrate $(y=261-1.11 \mathrm{x} ; p=0.014)$ but not to comparable measurements for fat, suggesting that carbohydrate but not fat has a nitrogen-sparing effect. For every carbohydrate kcal, $1.1 \mathrm{mg}$ of nitrogen was spared.

The energy expended by infants on the high-energy highcarbohydrate diet (group 4) was greater than the energy expended by infants on the high-fat diet at the same energy intake (group 3). Despite the higher energy balance (energy stored) of infants fed the high-carbohydrate diets, the energy stored per gram of weight gain was similar among the groups at both energy intakes $(2.5 \pm 0.3,2.5 \pm 0.5$, and $2.5 \pm 0.4 \mathrm{kcal} /$ $\mathrm{g} \Delta \mathrm{wt}$ in groups 1,2 , and control and $3.1 \pm 0.3$ and $2.9 \pm 0.4$ $\mathrm{kcal} / \mathrm{g} \Delta \mathrm{wt}$ in groups 3 and 4, respectively), suggesting that at similar gross energy intakes, the composition of the newly synthesized tissue did not differ in relation to quality of energy intake. The absolute amount of fat stored by infants on the high-carbohydrate diets was also greater, but the ratio of protein stored to fat stored (gram per gram) was similar (Table 5). Thus, both the energy stored per gram of weight gain and the protein/fat ratio of growth tissues suggest that the composition of the weight gained on the same gross energy intakes does not differ with the quality of energy.

As expected, the fat balance of infants on high-fat diets (groups 1 and 3) was greater than that of infants on the high-carbohydrate diets (groups 2 and 4). However, the fat retention as percent of the intake was significantly less on the high-fat diets $(79 \pm 3.5 \%$ versus $90 \pm 2.2 \%, p<0.01$ in groups 1 versus 2 and $83 \pm 5.8 \%$ versus $90 \pm 3.5 \%, p<0.05$ in groups 3 versus 4, respectively). Although the calcium balances did not differ among the groups, the urinary calcium excretion of the infants on the high-carbohydrate diets was greater than that of infants on the high-fat diets. The phosphorus balances of the infants on the high-carbohydrate diets were greater and their urinary phosphorus excretion was less than those of infants on the high-fat diets.

Biochemical variables. The mean plasma transthyretin concentration of infants did not differ among the groups (8.5 \pm $1.1,9.7 \pm 2.0,9.5 \pm 1.7$, and $9.4 \pm 2.5 \mathrm{mg} / \mathrm{dL}$ in groups 1 to 4 , respectively, and $8.5 \pm 2.1 \mathrm{mg} / \mathrm{dL}$ in the controls). The mean plasma albumin concentration of infants on the highcarbohydrate diet at the higher energy intake was significantly lower than that of infants on the high-fat diet at the same energy (3.4 \pm 0.3 versus $3.7 \pm 0.2 \mathrm{~g} / \mathrm{dL}, p<0.01)$; however, this difference was already apparent by the time the infants achieved full enteral intakes (i.e. $180 \mathrm{~mL} \cdot \mathrm{kg}^{-1} \cdot \mathrm{d}^{-1}$ ) of the study formulas. No difference was observed between groups at the lower energy intake $(3.6 \pm 0.2$ versus $3.4 \pm 0.2 \mathrm{~g} / \mathrm{dL}$ in groups 1 and 2, respectively). The plasma albumin concentration of infants on the control diet $(50 \%$ of the nonprotein energy as carbohydrate) was $3.5 \pm 0.2 \mathrm{~g} / \mathrm{dL}$.

The BUN concentration increased modestly over the study period, $0.84 \pm 1.3 \mathrm{mg} \cdot \mathrm{dL}^{-1} \cdot \mathrm{wk}^{-1}, p<0.001$. There was no difference among the groups in the rate of increase of BUN 
Table 3. Macronutrient balances of the five groups

\begin{tabular}{|c|c|c|c|c|c|}
\hline Variable $(\mathrm{kg} / \mathrm{d})$ & $\begin{array}{c}\text { Control } \\
130 \mathrm{kcal} \\
50 \% \mathrm{CHO} \\
(n=14)\end{array}$ & $\begin{array}{c}\text { Group } 1 \\
130 \mathrm{kcal} \\
35 \% \text { CHO } \\
(n=11)\end{array}$ & $\begin{array}{c}\text { Group } 2 \\
130 \mathrm{kcal} \\
65 \% \mathrm{CHO} \\
(n=12)\end{array}$ & $\begin{array}{c}\text { Group } 3 \\
155 \mathrm{kcal} \\
35 \% \mathrm{CHO} \\
(n=14)\end{array}$ & $\begin{array}{c}\text { Group } 4 \\
155 \mathrm{kcal} \\
65 \% \mathrm{CHO} \\
(n=12)\end{array}$ \\
\hline \multicolumn{6}{|l|}{ Nitrogen (mg) } \\
\hline Intake & $624.7 \pm 10.1$ & $652.3 \pm 1.5$ & $641.3 \pm 17.6$ & $649.7 \pm 12.9$ & $631.1 \pm 3.4$ \\
\hline Stool & $56.3 \pm 12.0$ & $63.5 \pm 23.4$ & $60.6 \pm 19.9$ & $73.6 \pm 17.8$ & $70.7 \pm 16.6$ \\
\hline Urine & $144.0 \pm 19.7$ & $168.6 \pm 34.9$ & $136.7 \pm 21.0 \dagger$ & $137.4 \pm 23.1$ & $101.2 \pm 27.4 \ddagger$ \\
\hline Gross intake & $130.0 \pm 1.6$ & $131.8 \pm 1.7$ & $129.2 \pm 4.6$ & $155.2 \pm 0.6$ & $152.8 \pm 1.0$ \\
\hline $\begin{array}{l}\text { Metabolizable } \\
\text { intake }\end{array}$ & $116.2 \pm 5.3$ & $113.6 \pm 5.3$ & $120.9 \pm 4.2 \dagger$ & $129.3 \pm 6.9$ & $142.4 \pm 2.4 \ddagger$ \\
\hline Energy expenditure & $63.3 \pm 4.4$ & $62.8 \pm 5.4$ & $63.8 \pm 2.8$ & $64.8 \pm 4.7$ & $69.1 \pm 3.49$ \\
\hline Energy stored & $52.9 \pm 8.1$ & $50.8 \pm 6.0$ & $57.1 \pm 5.7 \S$ & $64.5 \pm 7.3$ & $73.3 \pm 4.1^{* *}$ \\
\hline \multicolumn{6}{|l|}{ Fat $(g)$} \\
\hline Intake & $253.4 \pm 8.1$ & $239.8 \pm 14.8$ & $260.7 \pm 1.7$ & $254.8 \pm 2.7$ & $256.6 \pm 6.5$ \\
\hline Stool & $137.4 \pm 37.3$ & $132.9 \pm 40.6$ & $148.2 \pm 32.4$ & $159.4 \pm 46.0$ & $154.2 \pm 44.3$ \\
\hline Urine & $3.2 \pm 2.2$ & $1.9 \pm 1.2$ & $5.3 \pm 3.0 \|$ & $1.8 \pm 0.8$ & $5.2 \pm 3.1 \ddagger$ \\
\hline Balance & $112.8 \pm 40.7$ & $105.0 \pm 31.3$ & $107.2 \pm 31.3$ & $93.6 \pm 44.8$ & $97.2 \pm 48.0$ \\
\hline \multicolumn{6}{|l|}{ Phosphorus (mg) } \\
\hline Intake & $114.1 \pm 6.9$ & $114.1 \pm 6.6$ & $125.1 \pm 3.3$ & $118.1 \pm 2.6$ & $117.3 \pm 4.2$ \\
\hline Stool & $35.5 \pm 12.1$ & $42.5 \pm 15.9$ & $51.5 \pm 11.7$ & $48.2 \pm 7.0$ & $52.5 \pm 20.3$ \\
\hline Urine & $23.7 \pm 5.2$ & $24.6 \pm 6.9$ & $9.9 \pm 2.1 \|$ & $29.9 \pm 6.5$ & $9.0 \pm 3.7 \ddagger$ \\
\hline Balance & $54.9 \pm 10.8$ & $47.0 \pm 10.4$ & $63.7 \pm 11.7 \|$ & $40.0 \pm 7.9$ & $55.8 \pm 16.7 \ddagger$ \\
\hline
\end{tabular}

Mean \pm SD.

$\mathrm{CHO}=$ carbohydrate.

$\dagger, \S, \|$ Group $2 v s$ group $1, \dagger p \leq 0.01, \S p<0.05, \| p \leq 0.001$.

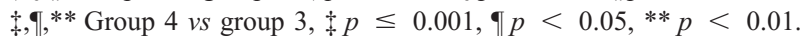

concentration. The mean BUN concentration of infants on the high-carbohydrate diets was significantly lower than that of infants on the high-fat diets $(7.2 \pm 1.6$ versus $9.6 \pm 2.7 \mathrm{mg} / \mathrm{dL}$, $p<0.01$ in group 2 versus 1 and $5.0 \pm 1.7$ versus $7.4 \pm 2.5$ $\mathrm{mg} / \mathrm{dL}, p<0.01$ in group 4 versus 3 ); however, like plasma albumin concentrations, these differences were already apparent by the time the infants achieved full enteral feeds (i.e. 180 $\left.\mathrm{mL} \cdot \mathrm{kg}^{-1} \cdot \mathrm{d}^{-1}\right)$ of the study formulas. The BUN concentration of infants on the control diet was $7.1 \pm 1.9 \mathrm{mg} / \mathrm{dL}$. The blood acid base status was within normal limits in all infants throughout the study period. With the exception of threonine and tyrosine, which were mildly elevated, the mean concentrations of all plasma amino acids were within the $95 \%$ confidence limits ( $\pm 2 \mathrm{SD}$ ) of cord plasma concentrations of similar gestational age preterm infants (22). The total plasma amino acid concentrations of infants on the high-carbohydrate diets were significantly lower than those of infants on the high-fat diets $(3540 \pm 474$ versus $4092 \pm 454 \mu \mathrm{mol} / \mathrm{L}, p<0.01$ in groups 2 versus 1 and $3455 \pm 296$ versus $3857 \pm 411 \mu \mathrm{mol} / \mathrm{L}, p<$ 0.05 in groups 4 versus 3 , respectively); however, again, these differences were already apparent by the time the infants achieved full enteral intakes of the formulas. The mean total plasma amino acid concentration of infants on the control diet was $3802 \pm 373 \mu \mathrm{mol} / \mathrm{L}$.

One infant randomized to group 3 who inadvertently did not get vitamin supplementation had low serum calcium levels

Table 4. Growth rates of the five groups

\begin{tabular}{|c|c|c|c|c|c|}
\hline Variable & $\begin{array}{c}\text { Control } \\
130 \mathrm{kcal} \\
50 \% \mathrm{CHO} \\
(n=14)\end{array}$ & $\begin{array}{c}\text { Group } 1 \\
130 \mathrm{kcal} \\
35 \% \mathrm{CHO} \\
(n=11)\end{array}$ & $\begin{array}{c}\text { Group } 2 \\
130 \mathrm{kcal} \\
65 \% \mathrm{CHO} \\
(n=12)\end{array}$ & $\begin{array}{c}\text { Group } 3 \\
155 \mathrm{kcal} \\
35 \% \mathrm{CHO} \\
(n=14)\end{array}$ & $\begin{array}{c}\text { Group } 4 \\
155 \mathrm{kcal} \\
65 \% \mathrm{CHO} \\
(n=12)\end{array}$ \\
\hline$\Delta$ Weight $\left(\mathrm{g} \cdot \mathrm{kg}^{-1} \cdot \mathrm{d}^{-1}\right)$ & $21.4 \pm 2.3$ & $20.2 \pm 1.8$ & $23.2 \pm 2.9 \#$ & $20.7 \pm 2.3$ & $24.9 \pm 2.4 t$ \\
\hline$\Delta$ Length $(\mathrm{cm} / \mathrm{wk})$ & $1.36 \pm 0.17$ & $1.26 \pm 0.35$ & $1.34 \pm 0.12$ & $1.34 \pm 0.12$ & $1.52 \pm 0.199$ \\
\hline$\Delta$ Head circumference $(\mathrm{cm} / \mathrm{wk})$ & $1.20 \pm 0.11$ & $1.19 \pm 0.29$ & $1.24 \pm 0.15$ & $1.15 \pm 0.15$ & $1.25 \pm 0.31$ \\
\hline $\begin{array}{l}\Delta \text { Triceps }+ \text { subscapular skinfold thickness } \\
(\mathrm{mm} / \mathrm{wk})\end{array}$ & $0.96 \pm 0.35$ & $0.89 \pm 0.30$ & $1.00 \pm 0.24$ & $0.93 \pm 0.38$ & $1.70 \pm 0.47+$ \\
\hline
\end{tabular}

Mean $\pm \mathrm{SD}$.

$\mathrm{CHO}=$ carbohydrate.

\# Group 2 vs group 1 , \# $p \leq 0.01$.

†. $\|$ Group $4 v s$ group $3, \ddagger p \leq 0.001, \rrbracket p<0.05$. 
Table 5. Composition of weight gained

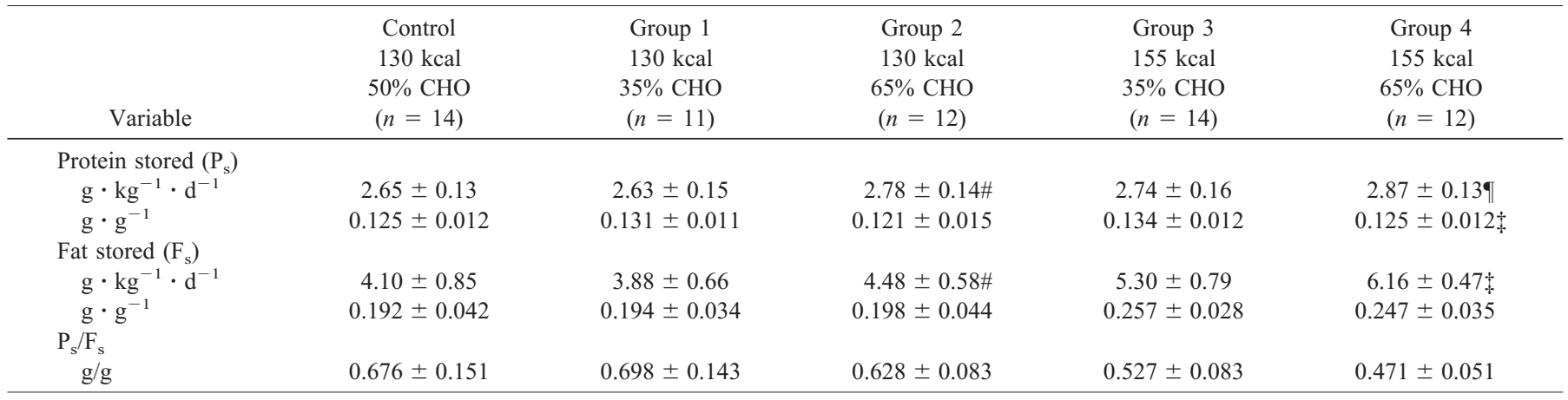

Mean \pm SD.

$\mathrm{CHO}=$ carbohydrate

\# Group 2 vs Group 1, \# $p \leq 0.05$.

†, Group 4 vs Group 3, $₫ p \leq 0.01, \boldsymbol{q} p<0.05$.

toward the end of the study. The calcium and phosphorus concentrations of all other infants were within normal limits during the study period. The plasma alkaline phosphatase activity increased during the study period by $32.9 \pm 33.9$ $\mathrm{U} \cdot \mathrm{L}^{-1} \cdot \mathrm{wk}^{-1}, p<0.001$. The rate of increase was significantly greater in the groups on the high-fat diets compared with the high-carbohydrate diets $(34.0 \pm 30.2$ versus $5.3 \pm 23.6 \mathrm{U}$. $\mathrm{L}^{-1} \cdot \mathrm{wk}^{-1}$ in group 1 versus $2, p<0.05$ and $71.3 \pm 41.6$ versus $20.3 \pm 42.9 \mathrm{U} \cdot \mathrm{L}^{-1} \cdot \mathrm{wk}^{-1}$ in group 3 versus $4, p<0.01$ ). The rate of increase of plasma alkaline activity in the control group was $33.6 \pm 23.0 \mathrm{U} \cdot \mathrm{L}^{-1} \cdot \mathrm{wk}^{-1}$.

Although the plasma triglyceride concentrations of infants on the high-carbohydrate diets were generally lower than those of the infants on the high-fat formulas, they were not significantly different $(57.4 \pm 14.3$ versus $86.4 \pm 17.9 \mathrm{mg} / \mathrm{dL}$ in group 2 versus 1 and $74.0 \pm 22.9$ versus $102.3 \pm 52.2 \mathrm{mg} / \mathrm{dL}$ in group 4 versus 3 , respectively). The mean concentration of plasma triglycerides of infants in the control group was $99.3 \pm$ $50.6 \mathrm{mg} / \mathrm{dL}$. Two infants had triglyceride concentrations $>200$ $\mathrm{mg} / \mathrm{dL}$ (one in group 3 and the other in the control group).

The rates of 24-h urinary C-peptide excretion in infants on the high-carbohydrate diets at both energy intakes were higher; however, they were not significantly different from those of infants on high-fat diets $(1.44 \pm 1.35$ versus $0.84 \pm 0.27$ $\mu \mathrm{g} \cdot \mathrm{kg}^{-1} \cdot \mathrm{d}^{-1}$ in group 2 versus 1 and $1.63 \pm 1.36$ versus $0.91 \pm$ $0.53 \mu \mathrm{g} \cdot \mathrm{kg}^{-1} \cdot \mathrm{d}^{-1}$ in group 4 versus 3 . C-peptide excretion of the control group was $0.77 \pm 0.50 \mu \mathrm{g} \cdot \mathrm{kg}^{-1} \cdot \mathrm{d}^{-1}$.

\section{DISCUSSION}

Our previous studies have shown that growth rate and nitrogen retention of enterally fed LBW infants improved with increased protein intake and/or increased energy intake $(4,13$, 23 ). The present study was designed to evaluate the effect of quality of nonprotein energy intake on growth, nitrogen retention and metabolic response of LBW infants. The results indicate that the rates of weight gain and nitrogen retention are greater when a higher proportion of the nonprotein energy is supplied as carbohydrate than as fat. This was true at two levels of gross energy intake (130 or $\left.155 \mathrm{kcal} \cdot \mathrm{kg}^{-1} \cdot \mathrm{d}^{-1}\right)$. These data support the hypothesis that high-carbohydrate diets compared with isocaloric high-fat diets are more effective in promoting growth and protein accretion in enterally fed LBW infants.

In this study, the fact that metabolizable energy was higher in the high-carbohydrate diet groups (due to mild steatorrhea in the high-fat intake groups) confounds the comparison of the specific effect of quality of energy on protein accretion. It raises the possibility that the enhanced growth was due merely to superior intestinal absorption of carbohydrate. There was too little variation in metabolizable energy to permit a withingroup analysis of the relationship between metabolizable energy and nitrogen balance/nitrogen excretion. However, it was possible to examine the relationship between the quality of metabolizable energy intake and nitrogen utilization. The data argue strongly that the superior retention of nitrogen is due to dietary carbohydrate rather than fat.

The greater nitrogen retention observed with higher carbohydrate intake at constant protein intakes is consistent with reports in adults of enhanced protein retention when carbohydrate is the primary energy substrate in both enteral $(8,9)$ and parenteral diets (10). Experimental observations regarding possible differential effects of carbohydrate versus fat energy on nitrogen retention in enterally fed LBW infants have not been reported previously. Published reports of effects of nonprotein energy on nitrogen retention are limited to parenterally fed infants, and results have been inconsistent. Some have reported increased (11), others unchanged (24-26), and some observers have reported decreased (27) nitrogen retention with higher carbohydrate intakes. An enteral feeding study investigating the effects of high-fat formulas on premature infants with bronchopulmonary dysplasia reported a greater rate of weight gain but no difference in nitrogen retention of infants on a high-carbohydrate ( $60 \%$ of nonprotein energy) versus a highfat ( $75 \%$ of the nonprotein energy) diet (28).

The hypothesis that the high-carbohydrate diets improve protein utilization in the enterally fed LBW infants is further supported by the finding that lower BUN and plasma amino acid concentrations of infants were observed on the highcarbohydrate diets compared with the infants fed the high-fat diets at both energy intakes. 
The nitrogen-sparing effect of carbohydrate is thought to be due to increased insulin secretion $(29,30)$. A significant correlation between urinary C-peptide (a subunit of the proinsulin molecule) and secretion rates of insulin has been demonstrated (31), and this measurement has been used as an index of integrated plasma insulin activity. The urinary C-peptide excretion of our LBW infants on the high-carbohydrate diets at both energy intakes, though higher, was not significantly different from that of infants on the high-fat diets.

Diets with lower protein energy (P:E) ratio have been associated with lower albumin concentrations $(32,33)$, suggesting that albumin concentrations are related not only to the absolute level of protein intake but also to the interaction between protein intake and energy intake. It has been noted in rats that dietary energy in excess of the amount needed for complete utilization of the protein intake was associated with lower plasma albumin concentrations (33). This was believed to be due to redistribution of protein in the body. Animals fed low $\mathrm{P}: \mathrm{E}$ ratio diets have been reported to have lower liver protein content and similar or greater skeletal muscle protein content (34). In this study, we evaluated the effect of quality of energy intake at two P:E ratios: a relatively high ratio of $3.2 \mathrm{~g}: 100 \mathrm{kcal}$ (groups 1, 2, and control) in which energy may be limiting (4, 23 ) and a lower ratio of $2.7 \mathrm{~g}: 100 \mathrm{kcal}$ (groups 3 and 4) in which energy was expected to be adequate or surfeit (13). Significantly lower albumin concentrations were observed in infants on the high-energy high-carbohydrate diet (group 4) compared with infants on the high-fat diet at the same energy intake. We speculate that the relatively excessive carbohydrate intake of the high-carbohydrate group diverted plasma amino acids to other tissues (e.g. skeletal muscle) than the liver, possibly due to the increased insulin secretion that is associated with the high-carbohydrate diets.

In our earlier studies and those of others, energy intake has been observed to exert a significant effect on energy expenditure $(3,23,35)$. Increased energy expenditure in relation to the quality of energy was only seen at the higher energy intake in group 4. This higher energy expenditure can be accounted for by the greater energy expended by this group for protein synthesis (higher nitrogen retention compared with group 3) and for lipogenesis from carbohydrate (greater fat stored than group 3). In adults receiving maintenance energy requirements, no differences in energy expenditure were reported as a function of quality of nonprotein energy $(36,37)$. In the parenterally fed newborn infant, some investigators have reported no difference in energy expenditure with isocaloric regimens providing glucose-lipid mixtures $(27,38,39)$, and others have noted increased energy expenditure with regimens providing glucose alone versus glucose + lipids (25). Increased energy expenditure has been reported with increasing glucose intake and is believed to be due to enhanced lipogenesis (40). It is to be expected that the total daily energy expenditure will not differ markedly if the fuel mixture used for meeting maintenance energy requirements is varied, because energy expenditure will be driven by energy needs. However, at excessive intakes, when energy is stored, the differential costs of storing fat directly versus synthesizing fat from carbohydrate, i.e. the differences in diet-induced thermogenesis, will be seen as an increase in total energy expenditure. The composition of weight gained was not influenced by the quality of energy but, as shown before $(3,4,23)$, was dependent on the nitrogen energy ratio of the diet.

Although no differences were observed in the calcium balances among the groups, the high-carbohydrate diets were associated with greater urinary excretion of calcium, greater phosphorus balance due to lower excretion of phosphorus, and a lower rate of increase in alkaline phosphatase activity during the study period. Increased calcium excretion has been reported in adults after ingestion of high-carbohydrate meals (41) and is thought to be due to the postprandial increase in plasma insulin levels, which may impair renal calcium absorption (42). Also, a decrease in plasma concentrations of phosphorus after ingestion of high-carbohydrate diets has been reported and is believed to be due to the transfer of phosphorus into the cells during glucose phosphorylation (43). Another possible contribution to the lower phosphorus excretion and greater phosphorus balance of infants on the high-carbohydrate diets is the greater rate of expansion of the intracellular space due to more rapid growth (greater rates of weight gain and nitrogen retention) observed in these infants.

This is the first prospective randomized investigation of effects of carbohydrate versus fat at two isonitrogenous gross energy intakes on the growth and metabolic response of enterally fed LBW infants. It should be noted that despite the lower coefficient of fat absorption with the high-fat formulas at both energy intakes, the formulas were well tolerated. The data from this controlled trial indicate that the relative proportions of fat and carbohydrate in the dietary fuel mix induce a multitude of potentially important differences in the biochemistry, physiology, and growth of LBW infants. At first pass, many of these effects appear desirable, i.e. weight gain is improved and nitrogen balance is improved; however, at higher gross energy intakes, other changes may be less advantageous, i.e. lower plasma albumin and plasma amino acid concentrations and relatively greater increase in skinfolds. Furthermore, substraterelated effects on such basic physiologic and behavioral variables as respiratory rate and heart rate have also been reported (44). There is not sufficient evidence available at this time to recommend a specific mixture of nonprotein energy for routine use in the nursery; however, it seems clear that the proportion of fat versus carbohydrate in the diet as well as the absolute energy and protein intake should be taken into account in the nutritional management of LBW infants. The data also support the concept that, kcal for kcal, fat and carbohydrate differ in a fundamental way in their roles in the energy economy of developing infants.

Acknowledgments. The authors thank the nurses of the Pediatric General Clinical Research Center and the Neonatal Unit at Babies and Children's Hospital of New York for their expertise, and Robert Sciacca and Steve Holleran for help with data analysis.

\section{REFERENCES}

1. American Academy of Pediatrics 1985 Committee on Nutrition: Nutritional needs of low-birth weight infants. Pediatrics 75:976-986 
2. American Academy of Pediatrics 1998 Committee on Nutrition: Nutritional needs of preterm infants. In: Kleinman RE (ed) Pediatric Nutrition Handbook. American Academy of Pediatrics, Elk Grove Village, IL, pp 55-87

3. Schulze K, Stefanski M, Masterson J, Spinnazola R, Dell R, Heird W 1987 Energy expenditure, energy balance, and composition of weight gain in low birth weight infants fed diets of different energy and protein content. J Pediatr 110:753-759

4. Kashyap S, Schulze K, Forsyth M, Zucker C, Dell R, Ramakrishnan R, Heird W 1988 Growth nutrient retention and metabolic response in low birth weight infants fed varying intakes of protein and energy. J Pediatr 113:713-721

5. Reichman B, Chessex P, Putet G, Verellen G, Smith JM, Heim T, Swyer PR 1981 Diet, fat accretion, and growth in premature infants. N Engl J Med 305:1495-1500

6. Whyte RK, Haslam R, Vlainic C, Shannon S, Samulski K, Campbell D, Bayley HS, Sinclair JC 1983 Energy balance and nitrogen balance in growing low birth weight infants fed human milk or formula. Pediatr Res 17:891-898

7. Catzeflis C, Schutz Y, Micheli JL, Welsch C, Arnaud MJ, Jequier E 1985 Whole body protein synthesis and energy expenditure in very low birth weight infants. Pediatr Res 19:679-687

8. Munro HN 1964 General aspects of the regulation of protein metabolism by diet and by hormones. III. Influence of dietary carbohydrate and fat on protein metabolism. In: Munro HN, Allison JB (eds) Regulation of Protein Metabolism in Mammalian Protein Metabolism, Vol 1. Academic Press, New York, pp 412-447

9. Richardson DP, Waylar AH, Scrimshaw NS, Young VR 1979 Quantitative effect of an isoenergetic exchange of fat for carbohydrate on dietary protein utilization in healthy young men. Am J Clin Nutr 32:2217-2226

10. Long JM, Wilmore DW, Mason AD, Pruit BA 1977 Effect of carbohydrate and fat intake on nitrogen excretion during total intravenous feeding. Ann Surg 185:417-422

11. Chessex P, Gagne G, Pineault M, Vaucher J, Bisaillon S, Brisson G 1989 Metabolic and clinical consequences of changing from high glucose to high fat regimens in parenterally fed newborn infants. J Pediatr 115:992-997

12. Jeejeebhoy KN, Anderson GH, Nakhooda AF, Greenberg GR, Sanderson I, Marliss EB 1976 Metabolic studies in total parenteral nutrition with lipid in man: comparison with glucose. J Clin Invest 57:125-136

13. Kashyap S, Forsyth M, Zucker C, Ramakrishnan R, Dell RB, Heird WC 1986 Effects of varying protein and energy intakes on growth and metabolic response in low birth weight infants. J Pediatr 108:955-963

14. Baginski ES, Foa PP, Zak B 1967 Microdetermination of inorganic phosphate, phospholipids, and total phosphate in biologic materials. Clin Chem 13:326

15. Miller DS, Payne PR 1965 A ballistic bomb calorimeter. Br J Nutr 13:501-508

16. Kleiber M 1974 The fire of life: an introduction to animal energetics. Krieger, Melbourne, FL, p 104

17. Lusk G 1961 Basal metabolism standards. In: Scientific Tables, 6th Ed, Documenta Geigy, Montreal, p 628

18. Food and Agricultural Organization of the United Nations, Ad Hoc Committee 1973 Energy and Protein Requirements. FAO Nutritional Series No. 7, Rome, p 1024

19. Widdowson EM 1974 Changes in body proportion during growth. In: Davis JA, Dobbing J (eds) Scientific Foundations of Pediatrics. Saunders, Philadelphia, pp 153-164

20. Shelley HJ 1964 Carbohydrate reserves in the newborn infant. BMJ 1:273-275

21. Netter J, Wasserman W 1974 Applied Linear Statistical Models; Regressions, Analysis of Variance, and Experimental Designs. Richard D Irwin Inc, Homewood, IL, pp $535-536$

22. Pittard WB, Geddes KM, Picone TA 1988 Cord blood amino acid concentrations from neonates of 23-41 weeks gestational age. JPEN 12:167-169

23. Kashyap S, Schulze KF, Ramakrishnan R, Dell RB, Heird WC 1994 Evaluation of a mathematical model for predicting the relationship between protein and energy intakes of low birth weight infants and the rate and composition of weight gain. Pediatr Res 35:704-712
24. Pineault M, Chessex P, Bisaillon S, Brisson G 1988 Total parenteral nutrition in the newborn infant: impact of the quality of infused energy on nitrogen metabolism. Am J Clin Nutr 47:298-304

25. Van Aerde JEE, Sauer PJJ, Pencharz PB, Smith JM, Swyer PR 1989 Effect of replacing glucose with lipid on the energy metabolism of newborn infants. Clin Sci 76:581-588

26. Pencharz PB, Beesley J, Sauer PJJ 1989 Total body protein turnover in parenterally fed neonates: effects of energy source studied by using $15 \mathrm{~N}$ glycine and $13 \mathrm{C}$ leucine. Am J Clin Nutr 50:1395-1400

27. Salas-Salvado J, Molina J, Figueras J, Masso J, Marti-Henneberg C, Jimenez R 1993 Effect of the quality of infused energy on substrate utilization in the newborn receiving total parenteral nutrition. Pediatr Res 33:112-117

28. Pereira GR, Baumgart S, Bennett MJ, Stallings VA, Georgieff MK, Hamosh M, Ellis L 1994 Use of high-fat formula for premature infants with bronchopulmonary dysplasia: metabolic, pulmonary, and nutritional studies. J Pediatr 124:605-611

29. Munro HN 1964 General aspects of the regulation of protein metabolism by diet and by hormones. III. Influence of dietary carbohydrate and fat on protein metabolism. In: Munro HN, Allison JB (eds) Regulation of Protein Metabolism in Mammalian Protein Metabolism, Vol. 1. Academic Press, New York, p 456

30. Fuller MF, Weeks TE, Cadenhead A, Bruce JB 1977 The protein sparing effect of carbohydrate. 2. The role of insulin. Br J Nutr 38:489-496

31. Meistas MT, Zadik Z, Margolis S, Kowarski AA 1981 Correlation of urinary excretion of C-peptide with the integrated concentration and secretion rate of insulin. Diabetes 30:639-643

32. Foman SJ, Ziegler EE, Nelson SE, Rogers RR, Frantz JA 1999 Infant formula with protein-energy ratio of $1.7 \mathrm{~g} / 100 \mathrm{kcal}$ is adequate but may not be safe. J Pediatr Gastroenterol Nutr 28:495-501

33. Lunn PG, Austin S 1983 Dietary manipulation of plasma albumin concentration. J Nutr 113:1791-1802

34. Coward WA, Whitehead RG, Lunn PG 1977 Reasons why hypoalbuminemia may or may not appear in protein energy malnutrition. Br J Nutr 38:115-126

35. van Goudoever JB, Sulkers EJ, Lafeber HN, Sauer PJJ 2000 Short term growth and substrate use in very-low-birth-weight infants fed formulas with different energy contents. Am J Nutr 71:816-821

36. Hill JO, Peters JC, Reed GW, Schlundt DG, Sharp T, Greene HL 1991 Nutrient balance in humans: effects of diet composition. Am J Clin Nutr 54:10-17

37. Verboeket-van-de Venne WPHG, Westerterp KR, ten Hoor F 1994 Substrate utilization in man: effects of dietary fat and carbohydrate. Metabolism 34:152-156

38. Chessex P, Belanger S, Piedboeuf B, Pineault M 1995 Influence of energy substrates on respiratory gas exchange during conventional mechanical ventilation of preterm infants. J Pediatr 126:619-624

39. Rubecz I, Mestyan J, Varga P, Klujber L 1981 Energy metabolism, substrate utilization, and nitrogen balance in parenterally fed post operative neonates and infants. The effect of glucose, glucose+amino acids, lipid+amino acids infused in isocaloric amounts. J Pediatr 98:42-46

40. Sauer PJ, Van Aerde JE, Pencharz PB, Smith JM, Swyer PR 1986 Glucose oxidation rates in newborn infants measured with indirect calorimetry and [U-13C] glucose. Clin Sci (Lond) 70:587-593

41. Lemann Jr J, Piering WR, Lennon EJ 1969 Possible role of carbohydrate-induced calciuria in calcium oxalate kidney-stone formation. N Engl J Med 280:232-237

42. DeFronzo RA, Cooke CR, Andres R, Faloona GR, Davies PJ 1975 The effect of insulin on renal handling of sodium, potassium, calcium, and phosphate in man. J Clin Invest 55:845-855

43. Maina G, Kessler RJ, Green DE 1975 Metal ion- and phosphate-mediated transport of glucose by insulin. Biochem Biophys Res Commun 67:1567-1574

44. Schulze KF, Kashyap S, Ramakrishnan R1993 Cardiorespiratory cost of growth. J Dev Physiol 19:85-93 